\title{
Determinan Penyebab Kejadian Stunting Pada Balita: Tinjauan Literatur
}

\author{
Malisa Ariani \\ Departemen Keperawatan Anak \\ Program Studi Ilmu Keperawatan \\ Universitas Sari Mulia \\ Banjarmasin
}

Korespondensi Penulis: Telepon: 081350067136,E-mail: sashaariani2323@gmail.com

DOI: $10.33859 / \mathrm{dksm} . \mathrm{v} 11 \mathrm{i1} .559$

\begin{abstract}
Abstrak
Latar Belakang: Stunting adalah kondisi badan kerdil/ pendek yang diakibatkan kekurangan gizi kronik yang tidak tertangani dengan baik dan segera. Stunting termasuk salah satu dari permasalahan gizi yang terjadi di dunia atau di Indonesia. Banyak faktor yang dapat menjadi penyebab terjadinya stunting.

Tujuan: Untuk mengulas faktor-faktor yang dapat menyebabkan terjadinya stunting pada balita seperti faktor pendidikan ibu, pengetahuan ibu, pemberian ASI ekslusif, pemberian MPASI, riwayat BBLR, riwayat penyakit infeksi, sanitasi, dan status sosial ekonomi keluarga.

Metode: Tinjauan literatur dilakukan melalui pencarian artikel yang relevan dari database elektronik (Google Scholar, DOAJ, Pubmed, portal garuda) dengan menggunakan kata kunci berikut: "stunting", "related factor", "children", "factor determinant", "kejadian stunting", "faktor terjadi stunting", "balita stunting". Ada 21 artikel yang didapatkan dengan batasan dari tahun 2016 - 2020 dan sudah dilakukan analisis mendalam.

Hasil: Faktor yang dapat menyebabkan terjadinya stunting pada balita diantaranya pendidikan ibu yang rendah dan pengetahuan ibu yang kurang pemahaman pemenuhan asupan nutrisi pada anak, tidak diberikan ASI ekslusif, pemberian MPASI yang tidak sesuai umur, riwayat BBLR, riwayat penyakit infeksi seperti penyakit ISPA dan diare berulang, sanitasi lingkungan yang buruk, dan status sosial ekonomi keluarga yang rendah dalam pemenuhan nutrisi pada anak.

Kesimpulan: Pentingnya tatalaksana yang dilakukan untuk mengatasi permasalahan stunting ini agar tidak menjadi salah satu permasalahan yang dapat menyebabkan gangguan pertumbungan dan perkembangan dikemudian hari.

Kata Kunci: faktor risiko, faktor determinan, kejadian stunting, balita
\end{abstract}




\title{
Determinant Causes Of Stunting Among Children Aged Under 5 Years : Literature Review
}

\begin{abstract}
Introduction: Stunting is a short body condition caused by chronic malnutrition that is not handled properly and immediately. Stunting is one of the nutritional problems that occur in the world or Indonesia. Many factors can cause of stunting.

Aim: To review the factors that can cause stunting among children aged under five years such as maternal education, maternal knowledge, exclusive breastfeeding, giving complementary food, low birth weight history, history of infectious diseases, sanitation, and socioeconomic status of the family.

Method: Literature review is carried out through searching relevant articles from electronic databases (Google Scholar, DOAJ, Pubmed, Garuda portal) using the following keywords: "stunting", "related factor", "children", "factor determinant”, "kejadian stunting", "faktor terjadi stunting", "balita stunting". There are 21 articles obtained with limitations from 2016 - 2020 and in-depth analysis has been done.

Result: Factors that can cause stunting in children ages under five yearse include low maternal education and knowledge of mothers who lack understanding of fulfilling nutritional intake in children, not given exclusive breastfeeding, giving complementary food that is not appropriate for age, LBW history, history of infectious diseases such as ISPA and recurrent diarrhea, poor environmental sanitation, and low socioeconomic status of the family in fulfilling nutrition in children.

Conclusion: The importance of management problem of stunting so that it does not become one of the problems that can cause growth and development problems in the future.
\end{abstract}

Keyword: risk factors, determinant factors, stunting, children under five years

\section{PENDAHULUAN}

Setiap Negara di Dunia mengalami permasalahan gizi dan Indonesia merupakan salah satu Negara dengan triple permasalahan gizi (stunting, wasting dan overweight). Angka kejadian stunting pada balita $(0-59$ bulan) di dunia sebesar $22,2 \%$ atau 150,8 juta (The Global Nutrition Report, 2018). Angka kejadian permasalahan stunting di Indonesia lebih tinggi dibandingkan dengan masalah gizi lainnya seperti wasting dan overweight. Hasil Riset Kesehatan Dasar (Riskesdas) tahun 2018 menunjukkan adanya penurunan prevalensi stunting ditingkat Nasional sebesar 6,4\%. Dimana pada tahun 2013, angka kejadian stunting sebesar $37,2 \%$ dan tahun 2018 sebesar 30,8\% atau sekitar 7 juta balita menderita stunting. Walaupun terjadi angka penurunan selama 5 tahun belakangan ini namun angka stunting tetap tinggi dan masih ada 2 (dua) provinsi dengan prevalensi di atas 40\% (Sulawesi Barat dan Nusa Tenggara Timur). 
Stunting merupakan istilah dari badan kerdil/ pendek, dimana anak usia dibawah 5 tahun mengalami kondisi gagal tumbuh akibat kekurangan gizi kronis dan infeksi berulang yang terjadi selama masa periode 1.000 Hari Pertama Kehidupan (HPK) yaitu dari janin hingga anak berusia 24 bulan. Anak dikatakan stunting jika hasil pengukuran antropometri dari panjang atau tinggi badan per usianya dibawah -2 SD (The Global Nutrition Report, 2018).

Stunting dapat menyebabkan organ tubuh tidak tumbuh dan berkembang secara optimal. Bhutta, et al (2013) menjelaskan jika balita yang mengalami stunting berkontribusi sebanyak 15\% (1,5 juta) kematian anak balita di dunia. Balita yang mengalami stunting juga dikhawatirkan akan menimbulkan dampak pada dirinya selama masa pertumbuhan dan perkembangan, baik dampak jangka pendek maupun dampak jangka panjang. Adapun dampak jangka pendeknya yaitu gagal tumbuh, hambatan perkembangan kognitif dan motorik, tidak optimalnya ukuran fisik tubuh serta mengalami gangguan metabolisme. Dampak jangka panjangnya meliputi menurunnya kapasitas intelektual, gangguan struktur dan fungsi saraf serta selsel otak permanen yang dapat menyebabkan penurunan kemampuan menyerap pelajaran di usia sekolah, menurunnya produktivitas saat dewasa dan meningkatkan timbulnya risiko penyakit tidak menular seperti hipertensi, penyakit jantung koronen, stroke dan diabetes melitus (Bhutta et al, 2013 dan Kakietek, et al, 2017 dalam Bappenas, 2018).

Terjadinya stunting dipengaruhi oleh banyak faktor, baik secara langsung seperti rendahnya asupan gizi dan status kesehatan, sedangkan penyebab tidak langsung seperti faktor pendapatan dan kesenjangan ekonomi, sistem pangan, sistem kesehatan, urbanisasi, dan lain-lain (Bappenas, 2018). Beberapa dari penelitian sebelumnya menyebutkan bahwa faktor penyebab kejadian stunting baik di dunia dan Indonesia meliputi kurang pengetahuan tentang stunting, kerawanan pangan, kelahiran prematur atau BBLR, pemberian ASI ekslusif, pengelolaan MPASI anak, sanitasi lingkungan, status sosial ekonomi keluarga yang rendah (Beal, et al, 2018; Bukusuba, et al, 2017; Masereka, et al, 2020).

Masih tingginya angka kejadian stunting dan banyaknya faktor penyebab terjadinya stunting maka perlu adanya intervensi yang terpadu, baik dari tenaga kesehatan ataupun berkolaborasi dengan tim multi-sektor yang harapannya bisa menurunkan angka kejadian stunting dan mengontrol faktor penyebab untuk menghambat timbulnya stunting serta dampaknya. Banyak penelitian juga menunjukkan bahwa stunting dapat diturunkan dengan memerangi faktor risiko stunting (Kurniadi, 2019).

Adapun tujuan dilakukan studi literatur ini adalah untuk mengetahui faktor-faktor 
yang dapat menyebabkan stunting pada anak usia dibawah 5 tahun.

\section{METODE}

Penelitian ini menggunakan pendekatan studi tinjauan literatur (literature review). Strategi pencarian literatur menggunakan database online yang terakreditasi, seperti Pubmed, DOAJ, Portal Garuda, dan Google Scholar. Literatur dibatasi dari tahun 2016 2020 dengan proses pencarian dilakukan dengan memasukkan keywords berbahasa Inggris dan Indonesia seperti "stunting", "related factor", "children", "factor determinant", "kejadian stunting", "faktor terjadi stunting”, "balita stunting”. Hal tersebut digunakan untuk meningkatkan sensitivitas dan spesifisitas hasil pencarian.

Tabel 1. Strategi Pencarian Literatur yang Relevan

\begin{tabular}{lcc}
\hline \multicolumn{1}{c}{ Data Based } & Temuan & Literatur Terpilih \\
\hline Google Scholar & 52 & 10 \\
Garuda & 69 & 6 \\
Pubmed & 12 & 3 \\
DOAJ & 20 & 2 \\
$\quad$ JUMLAH & 153 & 21 \\
\hline
\end{tabular}

\section{Tahapan Literatur Review}

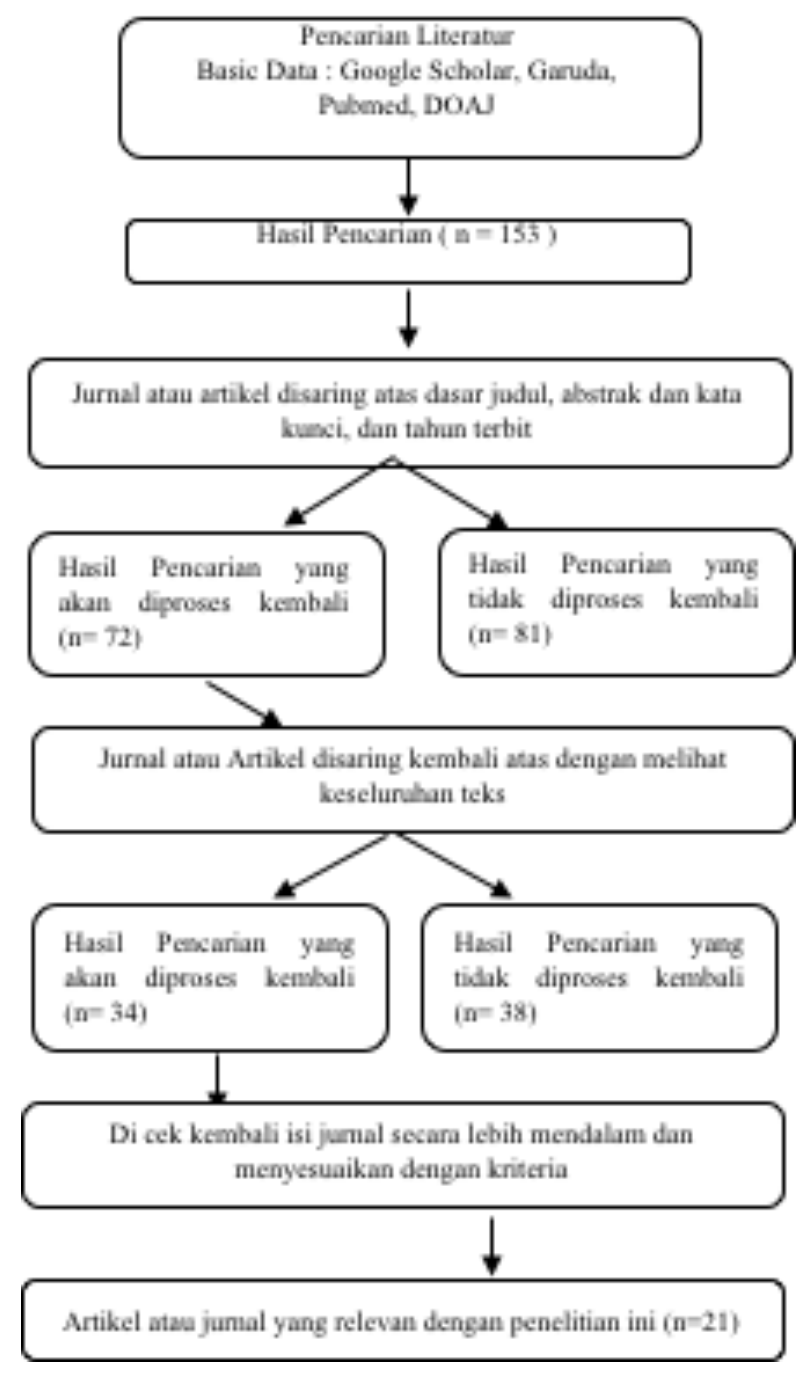

\section{HASIL}

Rangkuman dari 21 literatur yang menjadi faktor-faktor penyebab terjadinya stunting pada balita bisa di lihat pada tabel 2 matriks dibawah ini 
Tabel 2. Ringkasan Penyebab Kejadian

Stunting pada Balit

\begin{tabular}{|c|c|c|c|}
\hline $\begin{array}{l}\text { Author } \\
\text { (Years) }\end{array}$ & Language & $\begin{array}{c}\text { Elektronic } \\
\text { Based }\end{array}$ & Aim \\
\hline $\begin{array}{l}\text { Mugiati, dkk. } \\
2018\end{array}$ & Indonesia & DOAJ & $\begin{array}{l}\text { Menggambarkan } \\
\text { faktor penyebab } \\
\text { stunting pada anak } \\
\text { stunting usia } 25- \\
60 \text { bulan di } \\
\text { Kecamatan } \\
\text { Sukorejo } \\
\text { Blitar }\end{array}$ \\
\hline
\end{tabular}

Budiastutik, I Indonesia DOAJ Mengidentifikasi dan Rahfiludin, M. Z. 2019

Sastria, dkk. Indonesia Garuda 2019

Setiawan, Indonesia Garuda dkk. 2018 faktor risiko apa saja yang dapat menentukan terjadinya stunting anak di Negara berkembang
Mengetahui penyebab kejadian stunting pada balita dan anak di Wilayah Kerja Puskesmas

Lawawoi

Kecamatan Watang

Pulu Kabupaten Sidrap

\section{Design Findings}

Deskriptif Faktor penyebab stunting yaitu asupan energi rendah, penyakit infeksi, jenis kelamin laki-laki, Pendidikan ibu rendah, asupan protein rendah, tidak ASI ekslusif, Pendidikan ayah rendah dan ibu bekerja.

Literature Berdasarkan dari beberapa hasil Review penelitian bahwa salah satu penyebab stunting pada anak adalah karena tidak terpenuhinya gizi yang baik pada kurun waktu yang panjang dan sering tidak disadari oleh orangtua. Faktor risiko terjadinya stunting di Negara berkembang adalah panjang lahir, Pendidikan ibu yang rendah, anak yang tinggal didesa, BBLR, tidak ANC, tidak imunisasi, tidak ASI ekslusif

hubungan faktor

Mengetahui faktor- Observasio faktor yang nal berhubungan dengan dengan kejadian stunting pada anak usia $24-59$ bulan di Wilayah Kerja Puskesmas Andalas Kecamatan Padang Timur Kota Padang
Observasi Terdapat hubungan faktor onal pemberian ASI, pemberian dengan MPASI, dan pengetahuan pendekata orangtua terhadap kejadian $\mathrm{n}$ cross stunting. pendekata $\mathrm{n}$ cross sectional

Terdapat hubungan yang bermakna antara tingkat asupan energi, riwayat durasi penyakit infeksi, berat badan lahir, tingkat Pendidikan ibu dan tingkat pendapatan keluarga dengan kejadian stunting. Tingkat Pendidikan ibu memiliki hubungan yang dominan dengan kejadian stunting. 
Pibriyanti, dkk. 2019

Agustia, dkk. Indonesia 2018

Ariati, L. I. P. Indonesia 2019

\begin{abstract}
Hasan, A dan Indonesia Kadarusman,
\end{abstract} H. 2019

Mohammed, English et al. 2019
Garuda

Mengetahui faktor-

faktor yang

berhubungan

dengan kejadian

stunting pada balita

di wilayah kerja

Puskesma

Slogohimo

Kabupaten

Wonogiri

Garuda

Mengetahui faktor risiko ASI

eksklusif, penyakit infeksi dan status imunisasi dengan kejadian stunting pada balita usia 1259 bulan di Wilayah Tambang Poboya

Garuda

Mengetahui dan menganalisis

hubungan faktorfaktor resiko penyebab terjadinya stunting pada balita usia 23-59 bulan di desa Panduman

Menganalisis

hubungan antara akses terhadap sarana sanitasi dasar dengan kejadian stunting pada balita usia 659 bulan di Kabupaten

Lampung Timur Tahun 2018

Menentukan tingkat ketimpangan sosial ekonomi dan menguraikannya menjadi penentu sosial terjadi stunting pada anak dibawah usia 5 tahun di Ethiopia

Observasi Ada hubungan antara berat badan onal lahir, status ekonomi dan riwayat dengan penyakit infeksi dengan kejadian pendekata stunting pada balita.

$\mathrm{n}$ case

control

Survey analitik dengan pendekata n case control

CrossSectional

Adanya hubungan bermakna antara faktor prenatal (usia ibu saat hamil, status gizi ibu saat hamil), faktor pascanatal (ASI Eksklusif, riwayat imunisasi, penyakit infeksi), Karakteristik keluarga (pendidikan ibu, pekerjaan ayah dan status sosial ekonomi) dengan kejadian stunting.

Observasi Didapatkan dua variabel yang onal berhubungan dengan kejadian dengan stunting pada anak usia $6-59$ pendekata bulan yaitu akses ke jamban ncase sehat dan akses ke sumber air control bersih.

Survey

Hasil didapatkan bahwa angka Analitik ketimpangan sosial ekonomi tinggi penyebab stunting adalah pada warga miskin yang disebabkan karena status pendidikan oleh pengasuh. Selain itu ketimpangan status sosial lainnya dilihat dari wilayah tempat tinggal dan usia lahir anak. 
Torlesse,
al. 2016

Kwami, et

al. 2019

Maradzika, J, English et al. 2016

Sugiyanto, J, English dkk. 2019.
Mengidentifikasi

faktor yang

berhubungan

dengan kejadian stunting pada anak usia $0-23$ tahun di Indonesia
Cross Fasilitas sanitasi rumah tangga sectional dan pengolahan air minum Survey rumah tangga penyebab terjadinya stunting. Faktor risiko signifikan lainnya penyebab stunting termasuk jenis kelamin laki-laki, usia anak yang lebih tua, status kekayaan yang lebih rendah, tidak melakukan ANC ke faskes, dan tidak ada pratisipasi ibu dalam keputusan pembuatan makanan di rumah tangga

\begin{abstract}
Mengeksplorasi
hubungan antara stunting dan faktor air, sanitasi dan kebersihan di Ethiopia
\end{abstract}

Subset of a Upaya untuk meningkatkan wider perilaku mencuci tangan untuk controlled ibu dan anak dengan fokus pada trial akses ke air bersih. Banyaknya anak bertumbuh pendek ditinjau berdasarkan usianya maka intervensi lanjutan perlu upaya untuk meningkatkan gizi dan perilaku WASH (water, sanitation and hygiene) yang efektif dilakukan sejak dini

Cross Faktor utama penyebab stunting faktor yang berhubungan dengan stunting pada anak usia 0 59 bulan di Harare sectional di antara anak-anak $0-59$ bulan, Survey ditemukan kurangnya Pendidikan ibu, anak dikaitkan dengan ibu menjadi pengangguran, berada di pinggiran kota dengan kepadatan tinggi, anak pernah dirawat di RS, di susui setelah $>1$ jam kelahiran, MPASI $<6$ bulan, BBLR dan pola makan buruk

$\begin{array}{lccl}\text { Menguji faktor } & \begin{array}{c}\text { Analytic } \\ \text { kejadian } \\ \text { observati }\end{array} & \begin{array}{l}\text { Risiko yang menyebabkan } \\ \text { bentambahnya kejadian stunting }\end{array} \\ \text { stunting di Bontang, onal study } & \text { disebabkan oleh adanya angka } \\ \text { Kalimantan Timur, } & \text { witha } & \text { anggota keluarga }>\text {, riwayat } \\ \text { Indonesia } & \text { case } & \text { penyakit menular, sanitasi } \\ & \text { control } & \text { lingkungan yang buruk dan } \\ \text { design } & \text { BBLR. Sedangkan faktor risiko } \\ & & \text { yang menurunkan angka } \\ & \text { kejadian stunting yaitu tinggi ibu } \\ & >150 \text { cm, Pendidikan ibu } \\ & \text { minimal SMA lebih, ASI } \\ & \text { ekslusif dan status ekonomi } \\ & \text { tinggi. }\end{array}$


Yuniarti, T. Indonesia Google Menganalisis faktor S, dkk. 2019

Rohmawati, English $\mathrm{N}$ dan Antika R. B. 2017

Scholar stunting pada anak usia 1 - 2 tahun di daerah Rob

Kecamatan Pekalongan Utara

Google Mengetahui faktor Scholar risiko yang terkait dengan kejadian

$$
\text { risiko kejadian }
$$
stunting pada anak usia 6 - 36 bulan di Kabupaten Jember

Bukusuba, J, English et al. 2017

Teferi, M. B, English et al. 2016

Yanti, ND, Indonesia dkk. 2020
Google Scholar

Google Scholar

\begin{tabular}{|c|c|}
\hline $\begin{array}{l}\text { Mengidentifika } \\
\text { penyebab } \\
\text { yang mend } \\
\text { kejadian stu } \\
\text { dan terus me } \\
\text { tinggi di wil } \\
\text { Uganda } \\
\text { memiliki tir } \\
\text { kemiskinan } \\
\text { rendah dan } \\
\text { pertanian } \\
\text { tinggi }\end{array}$ & $\begin{array}{r}\text { fikasi } \\
\text { utama } \\
\text { endasari } \\
\text { stunting } \\
\text { menerus } \\
\text { wilayah } \\
\text { yang } \\
\text { tingkat } \\
\text { yang } \\
\text { hasil } \\
\text { yang }\end{array}$ \\
\hline
\end{tabular}

Menilai prevalensi stunting dan faktorfaktor terjadinya stunting pada anak usia $<5$ tahun di Ethiopia Barat Daya

Google Mengulas faktor Scholar yang menyebabkan stunting,

diantaranya

pengetahuan ibu dan pola asuh orang tua, asupan gizi, Berat Badan Lahir Rendah (BBLR), dan status ekonomi keluarga.
Observasi Asupan protein, asupan besi, onal kejadian diare, ISPA, riwayat dengan ASI Eksklusif, higiene sanitasi rancangan dan status ekonomi merupakan case faktor risiko terjadinya stunting control di daerah rob kota pekalongan

Observasi Stunting terjadi dari orangtua onal yang memiliki pendidikan dan dengan penghasilan rendah, pola asuh pendekata dan pola makan yang buruk, $\mathrm{n}$ cross tidak diberikan ASI ekslusif, sectional tidak pernah menderita penyakit infeksi dan memiliki ornagtua yang bertubuh pendek juga.

Case Rendahnya akses MPASI yang control tepat, jenis kelamin anak, kerawanan pangan, status sosial ekonomi yang buruk dan rendahknya pengetahuan tentang stunting adalah prediktor utama penyebab terjadinya stunting pada anak usia $6-59$ bulan

Cross Prevalensi stunting pada anak sectional usia $0-59$ bulan relative tinggi. Usia anak, usia mulai diberi MPASI dan jarak kelahiran ditemukan menjadi faktor yang terkait dengan kejadian stunting.

Literature Pengetahuan ibu dan pola asuh Review orang tua, asupan gizi, BBLR, dan status ekonomi diindikasikan sebagai faktor penyebab stunting di usia emas anak. Program yang didesain untuk meningkatkan pengetahuan orang tua seperti perawatan antenatal, pemantauan gizi ibu selama hamil, pemantauan gizi anak, dan informasi pola asuh direkomendasikan. 
Kurniadi， R. Indonesia 2019

Beal, T, et al. English 2017

Rahayu, M. Indonesia R. 2018
Google Scholar

Mengidentifikasi faktor-faktor penyebab terjadinya stunting pada anak usia di bawah 5 tahun (balita)

Google

Melakukan tinjauan Scholar literatur terbaru untuk menentukan terkait faktor penyebab stunting

Google

Analisis faktor biopsikososial dari stunting dan wasting pada anak usia $12-48$ bulan
Literature Faktor risiko terjadinya stunting Review adalah faktor maternal, faktor lingkungan rumah, faktor praktik pemberian makan dan ASI, dan faktor kejadian infeksi. Pengendalian stunting dapat dilakukan secara komprehensif dengan peningkatan pengetahuan ibu tentang nutrisi,, peningkatan akses makanan bergizi, serta akses terhadap air bersih, sanitasi yang baik, serta pelayanan kesehatan.

Literature Bukti yang didapatkan Review menunjukkan pemberian ASI non ekslusif selama 6 bulan pertama, rendah status social ekonomi rumah tangga, kelahiran premature, panjang badan lahir dan tinggi badan ibu yang rendah dan Pendidikan adalah faktor penentu terjadinya stunting pada anak yang sangat penting di Indonesia.

Analisis Faktor risiko stunting meningkay observasi pada pengetahuan ibu buruk, onal Pendidikan ibu rendah, status dengan nutrisi ibu buruk, berat badan desain lahir rendah, bayi tidak case- menerima ASI ekslusif control

\section{PEMBAHASAN}

Stunting dapat terjadi karena dipengaruhi oleh beberapa faktor. Berdasarkan hasil-hasil penelitian yang didapatkan menunjukkan bahwa faktor-faktor yang dapat mempengaruhi terjadinya stunting pada anak usia dibawah 5 tahun antara lain:

\section{Faktor Pendidikan Ibu}

Penelitian yang dilakukan oleh Setiawan, E., (2018) menjelaskan bahwa dari hasil analisis multivariat, faktor pendidikan ibu merupakan faktor yang memiliki hubungan paling dominan dengan kejadian stunting pada anak. Tingkat pendidikan memiliki peranan penting terhadap kesehatan, salah satunya terkait masalah status gizi. Seseorang yang berpendidikan tinggi memiliki kemungkinan 
lebih besar mengetahui cara menjaga tubuh yang baik dan pola hidup sehat yang ditandai dari penerapan konsumsi diet bergizinya dan biasanya cenderung menghindari kebiasaan buruk seperti rokok dan alkohol, sehingga memiliki status kesehatan yang lebih baik pula.

Maradzika, J, et al. (2016) dalam penelitiannya menjelaskan bahwa ibu yang berpendidikan tinggi akan membuat keputusan untuk meningkatkan asupan gizi dan kesehatan pada anak. Ibu yang memiliki tingkat pendidikan yang tinggi, harapannya juga dapat meningkatkan keuangan keluarga sehingga dapat meningkatkan pendapatan keluarga dan dapat membuat status asupan nutrisi lebih baik.

\section{Faktor Pengetahuan Ibu}

Penelitian dari Rahayu, dkk (2018) menunjukkan bahwa balita dengan ibu yang memiliki pengetahuan rendah akan memiliki risiko yang lebih besar untuk mengalami stunting. Hasil penelitian Sastria, dkk, (2019) menjelaskan bahwa terdapat hubungan yang signifikan antara faktor pengetahuan orangtua terhadap kejadian stunting pada balita dan anak. Bila pengetahuan orangtua kurang terkait cara pencegahan dan gizi baik pada anak, maka berisiko 11,13 kali anaknya mengalami stunting. Pada penelitian Olsa, Sulastri \& Anas (2017) menjelaskan bahwa pengetahuan sangat erat hubungannya dengan Pendidikan. Jika pendidikan seseorang tinggi, maka semakin luas juga pengetahuannya. Pendidikan yang rendah tidak menjamin ibu tidak memiliki pengetahuan yang cukup mengenai gizi untuk keluarganya. Adanya rasa ingin tahu yang tinggi dapat mempengaruhi ibu dalam mendapatkan informasi terkait makanan yang tepat untuk Kesehatan anak. Uliyanti, dkk (2017) dalam penelitiannya menjelaskan bahwa tinggi rendahnya pengetahuan gizi ibu akan memberikan perubahan pada status gizi. Semakin tinggi pengetahuan gizi ibu maka semakin baik pula status gizinya.

\section{Faktor Pemberian ASI Ekslusif}

Penelitian Rahayu, et al (2018) menunjukkan bahwa balita yang memiliki riwayat ASI non eksklusif akan berisiko lebih besar untuk menyebabkan anak mengalami stunting. Mugiati, dkk (2018) dalam penelitiannya menjelaskan bahwa ASI Ekslusif (ASI yang diberikan sejak lahir hingga usia anak 6 bulan) penting dalam pertumbuhan anak untuk mengurangi dan mencegah terjadinya penyakit infeksi pada anak dan mencegah stunting. Penelitian dari Yuniarti, T.S, dkk (2019) menunjukkan bahwa pemberian ASI eksklusif merupakan faktor risiko kejadian stunting. Anak kelompok stunting sebagian besar tidak diberikan ASI eksklusif. Anak yang tidak diberikan ASI eksklusif berisiko 19,5 kali untuk menjadi stunting.

\section{Faktor Pemberian MP-ASI}

Anak-anak yang diberikan makanan pendamping ASI tepat diusia 6 bulan menunjukkan risiko stunting yang lebih 
rendah daripada mereka yang menerima makanan pendamping ASI kurang atau lebih dari 6 bulan (Kurniadi, R, 2019). Teferi, M. B, et al (2016) menjelaskan dalam penelitiannya bahwa anak-anak yang memulai MPASI dibawah usia 6 bulan atau lebih dari usia 6 bulan berpotensi 3,78 kali kemungkinan berpengaruh pada terjadinya stunting dibandingkan anak yang diberi MPASI tepat di usia 6 bulan.

Menurut hasil penelitian Angkat (2018) dan Hasan \& Kadarusman (2019) menjelaskan bahwa bertambahnya umur bayi yang disertai kenaikan berat badan dan panjang badan, maka kebutuhan akan energi dan zat gizi lain akan bertambah pula. Kebutuhan gizi bertambah tidak hanya bisa diberikan ASI saja tapi harus ada makanan pendamping ASI yang menghasilkan energi sekurang-kurangnya mengandung 360 kkal per $100 \mathrm{~g}$ bahan. Penelitian Beal, T, et al (2017) menyimpulkan bahwa pengaruh MPASI dan stunting di Indonesia termasuk makanan berkualitas rendah, praktik pemberian makan yang tidak memadai dan keamanan makanan dan air yang digunakan

\section{Faktor Riwayat BBLR}

Hasil penelitian Pibriyanti, dkk (2019) didapatkan ada hubungan antara berat badan lahir dengan kejadian stunting. Responden yang memiliki BBLR mempunyai risiko 15,3 kali lebih besar menderita stunting dibandingkan bayi lahir dengan $\mathrm{BB}$ normal. $\mathrm{BB}$ lahir sangat berkaitan dengan pertumbuhan dan perkembangan jangka panjang. Dampak lanjutan dari BBLR dapat berupa gagal tumbuh dan jika seorang bayi lahir dengan BBLR maka dikhawatirkan akan kesulitan mengejar ketertinggalan pertumbuhan awal yang normal dan dapat berisiko menyebabkan anak menjadi stunting. Maradzika, J, et al (2016) dan Sugiyanto, J, et al (2019) menjelaskan bahwa BBLR secara signifikan menjadi faktor risiko terjadinya stunting. Berat lahir bayi dipengaruhi sejak masa pertumbuhan dalam kandungan dan asupan makanan ibu saat hamil. Jika pertumbuhan terhambat sejak dalam kandungan, maka ketika lahir, anak akan memiliki kemungkinan pertumbuhan yang terhambat pula. Maka dari itu, asupan nutrisi selama hamil harus diperhatikan sehingga kedepannya tidak terjadi permasalahan stunting.

\section{Faktor Riwayat Penyakit Infeksi}

Berdasarkan hasil penelitian Agustia, dkk (2018) didapatkan hasil bahwa riwayat penyakit infeksi merupakan faktor risiko stunting. Hasil uji statistik diperoleh $\mathrm{OR}=$ 3,400 yang artinya balita yang menderita penyakit infeksi berisiko 3,4 kali lebih besar mengalami stunting dibandingkan dengan balita yang tidak menderita penyakit infeksi. Tando (2012) dalam Ariati (2019) menjelaskan status kesehatan berupa frekuensi dan durasi sakit pada balita memberikan resiko kemungkinan terjadinya stunting pada anak. 
Terdapat hubungan timbal balik antara status gizi dan kejadian infeksi. Balita yang mengalami status gizi buruk dapat menyebabkan infeksi dikarenakan daya tahan tubuh rendah, sehingga akan mudah terserang penyakit. Sebaliknya, jika penyakit infeksi sering terjadi maka akan membuat seseorang mengalami malnutrisi dikarenakan adanya penurunan nafsu makan.

\section{Faktor Sanitasi}

Penelitian Rahayu, dkk (2018); Schmidt, C. W, 2014; Uliyanti, dkk, 2017 menunjukkan bahwa rumah tangga yang tidak memiliki akses air minum yang sesuai kriteria akan berisiko lebih besar untuk terjadinya stunting. Rendahnya kualitas sanitasi dan kebersihan lingkungan dapat memicu terjadinya penyakit gangguan saluran pencernaan yang berakibat energi yang dibutuhkan tubuh untuk pertumbuhan namun teralihkan digunakan bagi perlawanan tubuh melawan infeksi. Jika balita sering mengalami penyakit infeksi maka akan timbul masalah gizi, salah satunya stunting. Torlesse, $\mathrm{H}$, et al (2016) dalam penelitiannya menjelaskan peluang terjadinya stunting dan kaitannya dengan sanitasi dari hasil beberapa penelitian menunjukkan bahwa kejadian stunting lebih rendah pada rumah tangga yang memiliki akses ke fasilitas sanitasi yang lebih baik. Secara keseluruhan menurut penelitian Kwami, C. S, et al (2019) yaitu faktor water, sanitation, and hygiene (WASH) merupakan faktor yang dapat menyebabkan stunting. Namun tidak cukup melakukan WASH saja untuk mencegah stunting, tapi banyak faktor penyebab terjadinya stunting yang harus dicegah/ diatasi. Penelitian ini memberikan program rekomendasi WASH untuk mencegah terjadinya stunting yaitu 1) memperkuat upaya untuk meningkatkan perilaku mencuci tangan untuk ibu dan anak, 2) memprioritaskan akses ke sumber air bersih, dan 3) mendukung pelaksanaan WASH.

\section{Faktor Status Ekonomi Keluarga}

Balita dari keluarga dengan pendapatan perkapita kurang memiliki resiko 5,385 kali mengalami stunting dibandingkan dengan balita dari keluarga dengan pendapatan cukup. Status ekonomi kurang dari keluarga menyebabkan daya beli kurang terhadap makanan yang memiliki zat gizi baik sehingga berisiko terjadinya kekurangan zat gizi makro dan mikro, kekurangan zat gizi pada balita atau ibu hamil dapat meningkatkan resiko terjadinya stunting pada anak (Margawati, A \& Astuti, A. M., 2018; Aini et al., 2018; Yanti, N. D, dkk, 2020). Hasil penelitian didapatkan bahwa kejadian stunting lebih banyak terjadi pada sosial ekonomi yang rendah. Stunting yang terjadi pada warga miskin disebabkan karena rendahnya pemahaman tentang gizi dan pengelolaan diet serta praktik kebersihan diri (Mohammed, S. H, et al, 2019). Utami, dkk (2017) dan Omondi \& Kirabira (2016) melaporkan hal yang sama bahwa pendapatan keluarga mempengaruhi kejadian stunting pada 
balita. Pendapatan keluarga terkait pemenuhan asupan energi dan protein untuk anak bisa menjadi faktor tidak langsung terkait kejadian stunting. Penghasilan keluarga terkait dengan penyediaan makanan keluarga, akses mendapatkan makanan dikeluarga dan distribusi makanan yang memadai untuk keluarga dapat menjadi faktor risiko terhambatnya pertumbuhan.

\section{KESIMPULAN}

Banyak faktor yang dapat menyebabkan terjadinya stunting pada balita diantaranya pendidikan ibu yang rendah dan pengetahuan ibu yang kurang pemahaman pemenuhan asupan nutrisi pada anak, tidak diberikan ASI ekslusif, pemberian MPASI yang tidak sesuai umur, riwayat BBLR, riwayat penyakit infeksi seperti penyakit ISPA dan diare berulang, sanitasi lingkungan yang buruk, dan status sosial ekonomi keluarga yang rendah dalam pemenuhan nutrisi pada anak. Hendaknya faktor-faktor ini dapat diatasi dalam lingkup kesehatan atau lintas sektor agar kejadian stunting baik di Indonesia atau di Dunia tidak terjadi lagi sehingga masa depan anak tidak terhambat karena permasalahan gizi. Edukasi sangat penting juga di berikan untuk meningkatkan pemahaman orangtua terutama ibu terkait pemenuhan gizi untuk keluarganya untuk mencegah kejadian stunting pada anak

\section{IMPLIKASI PENELITIAN}

Masih banyaknya kejadian stunting dilihat dari hasil tinjauan literatur ini maka harapannya ada upaya tindak lanjut dalam mengatasi permasalahan stunting ini baik dari tatalaksana lingkup keluarga, tenaga kesehatan atau lintas sektor.

\section{UCAPAN TERIMA KASIH}

Peneliti mengucapkan terimakasih sebesarbesarnya kepada rekan-rekan di Program Studi Sarjana Keperawatan dan Profesi Ners Universitas Sari Mulia beserta keluarga yang telah memberikan semangat dalam menyelesaikan penelitian ini.

\section{DAFTAR PUSTAKA}

Development Initiatives. (2018). 2018 Global Nutrition Report: Shining a light to spur action on nutrition. Bristol, UK: Development Initiatives. https://globalnutritionreport.org/reports /global-nutrition-report-2018/ - Diakses Juni 2020

Riset Kesehatan Dasar(Riskesdas). (2018). Badan Penelitian dan Pengembangan Kesehatan Kementerian RI tahun 2018. http://www.depkes.go.id/resources/dow nload/infoterkini/materi_rakorpop_201 8/Hasil\%20Riskesdas\%202018.pdf Diakses Juni 2020

Bappenas. (2018). Rencana Aksi Nasional Dalam Rangka Penurunan Stunting. Rembuk Stunting: Jakarta. 
Beal, T., Tumilowicz, A., Sutrisna, A., Izwardy, D., Lynnette, M.N. (2018). A review of child stunting determinants in Indonesia. Wiley Maternal \& Child Nutrition. 14:e12617, page $1-10$

Bukusuba, J., Kaaya, N.A., Atukwase, A. (2017). Predictor of Stunting in Children Aged 6 to 59 Months: A CaseControl Study in Southwest Uganda. Food and Nutrition Bulletin. 38(4), page $542-553$

Masereka, E. M., Kiconco, A., Katsomyo, E., Munguiko, C. (2020). The Prevalence and Determinants of Stunting among Children 6-59 Months of Age in One of the Sub-Countries in the Rwenzori Sub-Region Western Uganda, Open Journal of Nursing, 10, page: $239-251$

Kurniadi, R. (2019). Faktor-faktor Risiko Terjadinya Stunting Anak Usia di Bawah 5 Tahun. Jurnal Penelitian Kesehatan Suara Forikes, vol. 10 No 4, hal 275 - 280

Rohmawati, N, \& Antika R. B. (2017). Risk Factors Stunting Incidence in Children Aged 6- 36 Months in Jember Regency. International Nursing Conference. Page: 128 - 136

Mugiati, S., Mulyadi, A., Anam, A. K., Najah, Z. L. (2018). Faktor Penyebab Anak Stunting Usia $25 \quad-60$ bulan di Kecamatan Sukorejo Kota Blitar. Jurnal Ners dan Kebidanan, vol. 5, no. 3. Hal: $268-278$

Agustia, R., Rahman, N., \& Hermiyanty. (2018). Faktor Risiko Kejadian Stunting pada Balita Usia12 - 59 Bulan di Wilayah Tambang Poboya, Kota Palu. Ghidza: Jurnal Gizi dan Kesehatan, 2(2), hal $59-62$
Budiastutik, I, \& Rahfiludin, M. Z. (2019). Faktor Risiko Stunting pada Anak di Negara Berkembang. Amerta Nutr. Hal $122-126$

Sastria, A., Hasnah., \& Fadli. (2019). Faktor Kejadian Stunting pada Anak dan Balita. Jurnal Ilmiah Keperawatan STIKES Hang Tuah Surabaya, vol. 14, no. 2 , hal. $100-108$

Setiawan, E., Machmud, R., \& Masrul. (2018). Faktor-faktor yang Berhubungan dengan Kejadian Stunting pada Anak Usia 24 - 59 Bulan di Wilayah Kerja Puskesmas Andalas Kecamatan Padang Timur Kota Padang Tahun 2018. Jurnal Kesehatan Andalas, 7 (2), hal: 275 - 284

Pibriyanti, K, Suryono, Luthfi, C.A. (2019). Faktor-faktor yang Berhubungan dengan Kejadian Stunting pada Balita di Wilayah Kerja Puskesmas Slogohimo Kabupaten Wonogiri. Darussalam Nutrition Journal, 3(2), hal: 42 - 49

Teferi, M. B, et al. (2016). Prevalence of Stunting and Associated Factors among Children Aged 06 - 59 Months in Southwest Ethiophia: A CrossSectional Study. Nutrition Health Food Sci, 4(3). Page: 1-6

Sugiyanto, J., Raharjo, S. S., \& Dewi, Y. L. R. (2019). The Effects of Exclusive Breastfeeding and Contextual Factor of Village on Stunting in Bontang, East Kalimantan, Indonesia. Journal of Epidemiology and Public Health, 4(3), Page: 222-233

Torlesse, H., Cronin, A. A., Sebayang, S. K., Nandy, R. (2016). Determinants of Stunting in Indonesia Children: Evidence From A Cross-Sectional Survey Indicate a Prominent Role for the Water, Sanitation, and Hygiene Sector in Stunting Reduction. BMC Public Health. 16: 669. Page: 1 - 11 
Ariati, L. I. P. (2019). Faktor-faktor Resiko Penyebab Terjadinya Stunting pada Balita Usia 23 - 59 Bulan. Oksitosin, Kebidanan, Vol. VI, No. 1. Hal: 28 - 37

Hasan, A., \& Kadarusman, H. (2019). Akses ke Sarjana Sanitasi Dasar sebagai Faktor Risiko Kejadian Stunting pada Balita Usia 6 - 59 Bulan. Jurnal Kesehatan. Vol 10, No.3. Hal: 413 421

Mohammed, A. H., Muhammad, F., Pakzad, R., Alizadeh, S. (2019). Socioeconomic Inequality in Stunting Among Under-5 Children in Ethiopia: A Decomposition Analysis. BMC Research Notes, 12: 184. Page: $1-5$

Kwami, C. S., et al. (2019). Water, Sanitation, and Hygiene: Linkages with Stunting in Rural Ethiopia. Int J Environ Res Public Health, 16(20): 3793. Page: 1 - 21

Maradzika, J., Makwara, I. P., Chipunza, S. (2016). Factors Associated with Stunting among Children Aged 0 - 59 Months in Harare City, Zimbabwe. International Journal of Child Health and Nutrition, 5, Page: 31-44

Yuniarti, T. S., Margawati, S., \& Nuryanto. (2019). Faktor Risiko Kejadian Stunting Anak Usia 1 - 2 Tahun di Daerah Rob Kota Pekalongan. Jurnal Riset Gizi, Vol.7 No.2, Hal: 83 - 90

Yanti, N. D., Betriana, F., \& Kartika, I. R. (2020). Faktor Penyebab Stunting pada Anak: Tinjauan Literatur. REAL in
Nursing Journal (RNJ), Vol. 3, No.1, Hal: $1-10$

Rahayu, R. M., Pamungkasari, E. P., \& Wekadigunawan, C.S. P. (2018). The Biopsychosocial Determinants of Stunting and Wasting in Children Aged 12-48 Months. Journal of Maternal and Child Health, 3(2), Hal: 105-118

Olsa, E, D., Sulastri, D., \& Anas, E. (2017). Hubungan Sikap dan Pengetahuan Ibu terhadap Kejadian Stunting pada Anak Baru Masuk Sekolah Dasar di Kecamatan Nanggalo. Jurnal Kesehatan Andalas, 6(3), hal: 523 - 529

Uliyanti, Tamtomo, D. G., Anantanyu, S. (2017). Faktor yang Berhubungan dengan Kejadian Stunting pada Balita Usia 24 - 59 Bulan. Jurnal Vokasi Kesehatan, 3 (2), Hal: 67 - 77

Angkat, A. H. (2018). Penyakit Infeksi dan Praktek Pemberian MP-ASI Terhadap Kejadian Stunting Pada Anak Usia 1236 Bulan di Kecamatan Simpang Kiri Kota Subulussalam. Jurnal Dunia Gizi, 1(1). Hal: 52- 58.

Schmidt, Charles, W. (2014). Beyond Malnutrition: The Role of Sanitation in Stunted Growth. Environmental Health Perspectives. 122.11: A298.

Utami AD, Indarto D, Dewi YLR. (2017). The Effect of Nutrient Intake and Socioeconomic Factor Toward Stunting Incidence Among Primary School Students in Surakarta. 2(1), page: 1-1 